Proceedings

\title{
Identification and Validation of Operational Welfare Indicators Appropriate for Small-Scale Goat Farming in Chile ${ }^{+}$
}

\author{
Jaqueline Rodriguez ${ }^{1}$, Mario Morales ${ }^{2}$ and Hernan Cañon-Jones ${ }^{1, *}$ \\ 1 Núcleo de Investigación Aplicada en Ciencias Veterinarias y Agronómicas, Facultad de Medicina \\ Veterinaria y Agronomía, Universidad de Las Américas, 7500975 Santiago, Chile; jaki_ro@live.cl \\ 2 Programa de Desarrollo Local, Instituto de Desarrollo Agropecuario e Ilustre Municipalidad de Lampa, \\ 9380000 Lampa, Chile; moralesc77@gmail.com \\ * Correspondence: hcanon@udla.cl \\ † Presented at the 1st International Electronic Conference on Animals-Global Sustainability and Animals: \\ Science, Ethics and Policy, 5-20 December 2020; Available online: https://ieca2020.sciforum.net/.
}

Citation: Rodriguez, J.; Morales, M.; Cañon-Jones, H. Identification and Validation of Operational Welfare Indicators Appropriate for SmallScale Goat Farming in Chile. Proceedings 2021, 73, 13. https://doi.org/ 10.3390/IECA2020-08829

Published: 2 December 2020

Publisher's Note: MDPI stays neutral with regard to jurisdictional claims in published maps and institutional affiliations.

Copyright: $@ 2020$ by the authors. Licensee MDPI, Basel, Switzerland. This article is an open access article distributed under the terms and conditions of the Creative Commons Attribution (CC BY) license (http://creativecommons.org/licenses/by/4.0/).

\begin{abstract}
Goat production in Chile is carried by small-scale farmers obtaining milk and cheese as the main products. The welfare of goats under these types of production systems is currently unknown and no appropriate validated operational welfare indicators are currently available. We took the tasks of identifying operational welfare indicators and validating them with all stakeholders. A total of 37 operational welfare indicators were obtained. The use of these validated indicators and the welfare score is appropriate to Chilean goat production systems and may successfully increase the sustainability of production and farmers in Chile.
\end{abstract}

Keywords: behaviour; sustainable; value-added; appropriate; welfare

\section{Introduction}

Goat production in Chile is carried out by poor small-scale farmers in semi-arid to arid agricultural conditions [1]. Milk and cheese are the main products obtained using artisanal, cultural, and traditionally-preserved methods where women and children are usually in charge of production [2]. The products are directly consumed by the family or sold to passers-by at good prices [3]. These production systems are similar in goat production around the world, especially in developing countries in the Americas and Africa.

Goats are adapted to higher temperatures and may seem suitable and sustainable animal for production under current global warming status in some areas of the world [4-6]. The interest in the welfare of production animals including goats has been increasing in recent years, both for milk and meat goat production systems $[7,8]$. Numerous studies have been carried out identifying potential welfare indicators for goats. Some on-farm goat welfare assessments based on qualitative and quantitative variables have been developed for intensive systems in Europe [9,10]. However, goat welfare under extensive systems in semi-arid areas of Chile is currently unknown and no appropriate validated operational welfare indicators are currently available. The incorporation of a welfare assessment system may also increase milk yield and cheese production, and may provide an extra added-value as demonstrated in other countries $[8,11]$. The aim of this work was to obtain appropriate operational welfare indicators (AOWI) for small goat farmers in Chile.

\section{Materials and Methods}

We first identified all possible goat welfare indicators described in the scientific literature by searching in databases such as Scopus, Web of Science, Scielo, and Pubmed. The welfare indicators were categorized as either direct or indirect, and a tabulated accordingly. 
We then followed the guidelines of the European Food Safety Agency to validate the indicators with the relevant stakeholders [12]. Briefly, hazard analysis and critical control point methodology was used to validate indicators with the relevant stakeholder, which included farmers, staff working with goats, veterinarians, and animal welfare experts. A questionnaire was constructed in which each stakeholder had to evaluate the identified indicator for its perceived impact of animal welfare (magnitude) and its perceived easiness to measure (operational effectiveness) using a Likert scale (0 to 5$)$. Any indicator with $60 \%$ of approval was considered to be validated by stakeholders.

A further on-farm real validation using the selected indicators was carried out to ensure their practicability and ease of measurement using a Likert scale from 1 to 5 . This was carried out at four different farms in five different times. All indicators that had a score of $60 \%$ or more were finally classified as appropriate operational welfare indicator (AOWI).

All national and institutional ethical recommendations and guidelines were followed in order to preserve ethical integrity during the study.

Using the AOWI, we implemented a Goat Welfare Score system ranging from $0 \%$ to $100 \%$ of welfare, using a linear model where each indicator had a different weight according to the hazard analysis.

\section{Results}

We identified 48 welfare indicators in the peer-review literature. Only 40 of the initial welfare indicators were validated by goat production stakeholders (farmers, veterinarians, technicians, welfare experts) using the European Food Safety Agency guidelines. After the on-farm validation, 33 operational welfare indicators were obtained (Table 1). A welfare score system was developed including all indicators and validated in normal production conditions.

Table 1. Appropriate operational welfare indicators or goats according to type of indicators.

\begin{tabular}{ll}
\hline \multicolumn{1}{c}{ Direct Indicator } & \multicolumn{1}{c}{ Appropiate Operational Welfare Indicator } \\
\hline Vocalization & Presence of rest area \\
Cleaning of the rear train and belly & Man-animal/operator relationship \\
Condition of nose & Water Quality \\
Alert attitude & Available accommodation space \\
Limping & Eyelet quality \\
Hydration & Grazing population density \\
Herd separation & Shelter (shade and rain) \\
Gaming behavior & Amount of food \\
Condition of breast rooms & Food quality \\
Time at rest & Availability of water \\
Condition of ear secretions & \\
Expression of Social Behavior & \\
Mastitis & \\
Thermal stress & \\
Bodily Injury & \\
Skin condition & \\
Hoof condition & \\
Injuries to members & \\
Body condition & \\
Breathing & \\
Travel activity & \\
Weight of the animal & \\
Kneeling for food &
\end{tabular}




\section{Discussion}

Our study showed that not all welfare indicators are well suited for different production system worldwide. Our study eliminated $32 \%$ of indicators that were identified in the scientific literature, indicating that some of them are either not practical in normal production conditions or that stakeholders do no not know them. This is important considering the local, economic, and educational level of farmers in every country or territory. Furthermore, a deeper analysis shows that even after validation by stakeholders, some indicators failed to be practical or operational. These results showed the relevance of incorporating the actual farmers, technical staff, and field veterinarians, into the validations of welfare indicators, rather than keeping the validation at an academic level exclusively. The use of these validated indicators and the welfare score are appropriate to the local Chilean goat production systems and may successfully increase the sustainability of production and farmers in Chile. Further studies should be focused on the temporal measurements of the AOWI and modifications to the mathematical welfare score system developed here.

Author Contributions: Conceptualization, H.C.-J.; methodology, J.R., H.C.-J.; validation, M.M.; formal analysis, H.C.-J. and J.R.; investigation, J.R.; data curation, H.C.-J.; writing-original draft preparation, H.C.-J.; writing - review and editing, J.R., M.M. and H.C.-J.; supervision, H.C.-J. and M.M. All authors have read and agreed to the published version of the manuscript.

Funding: This research received no external funding.

Institutional Review Board Statement: Ethical review and approval were waived for this study, due to no critical personal information was obtained.

Informed Consent Statement: Informed consent was obtained from all subjects involved in the study.

Conflicts of Interest: The authors declare no conflict of interest.

\section{References}

1. ODEPA Estadísticas Productivas-ODEPA-Ministerio de Agricultura de Chile. Available online: http://www.odepa.cl/estadisticas/productivas/(accessed on 28 June 2017).

2. Pizarro Silva, N.F. Descripción de la situación actual de la producción y comercialización de queso de cabra producido por la agricultura familiar en la Región de Coquimbo. Bachelor's Thesis, Universidad de Chile, Santiago, Chile, 2015.

3. Diez-de-Medina, R.S.; Cabello, P.; Rios, J.C.; Figueroa, P.; Balic, I.; Hardy, D.; Vrsalovic, V. Socio-Technological Characterization of Goat Industry at Tamarugal Province in Atacama Desert. J. Technol. Manag. Innov. 2015, 10, 53-59, doi:10.4067/S071827242015000300006.

4. Chingala, G.; Mapiye, C.; Raffrenato, E.; Hoffman, L.; Dzama, K. Determinants of smallholder farmers' perceptions of impact of climate change on beef production in Malawi. Clim. Chang. 2017, 142, 129-141, doi:10.1007/s10584-017-1924-1.

5. Chedid, M.; Tourrand, J.-F.; Jaber, L.S.; Hamadeh, S.K. Farmers' perception to change and adaptation strategies of small ruminant systems in the West Bekaa of Lebanon. Small Rumin. Res. 2018, 167, 16-21, doi:10.1016/j.smallrumres.2018.07.025.

6. Feleke, F.B.; Berhe, M.; Gebru, G.; Hoag, D. Determinants of adaptation choices to climate change by sheep and goat farmers in Northern Ethiopia: The case of Southern and Central Tigray, Ethiopia. SpringerPlus 2016, 5, 1692, doi:10.1186/s40064-016-3042-3.

7. Marína, M.P.; Fuenzalidaa, M.I.; Burrowsb, J.; Gecelea, P. Somatic cell count and composition of dairy goat milk according to milk yield and lactation period under intensive management system, in the central region of Chile [Recuento de células somáticas y composición de leche de cabra, según nivel de producción y etapa de lactancia, en un plantel intensivo de la zona central de Chile]. Arch. Med. Vet. 2010, 42, 79-85.

8. Tiezzi, F.; Tomassone, L.; Mancin, G.; Cornale, P.; Tarantola, M. The Assessment of Housing Conditions, Management, AnimalBased Measure of Dairy Goats' Welfare and Its Association with Productive and Reproductive Traits. Animals 2019, 9, 893, doi:10.3390/ani9110893.

9. Grosso, L.; Battini, M.; Wemelsfelder, F.; Barbieri, S.; Minero, M.; Dalla Costa, E.; Mattiello, S. On-farm Qualitative Behaviour Assessment of dairy goats in different housing conditions. Appl. Anim. Behav. Sci. 2016, 180, 51-57, doi:10.1016/j.applanim.2016.04.013.

10. Battini, M.; Barbieri, S.; Vieira, A.; Can, E.; Stilwell, G.; Mattiello, S. The Use of Qualitative Behaviour Assessment for the OnFarm Welfare Assessment of Dairy Goats. Animals 2018, 8, 123, doi:10.3390/ani8070123. 
11. Morand-Fehr, P.; Boutonnet, J.P.; Devendra, C.; Dubeuf, J.P.; Haenlein, G.F.W.; Holst, P.; Mowlem, L.; Capote, J. Strategy for goat farming in the 21st century. Small Rumin. Res. 2004, 51, 175-183, doi:10.1016/j.smallrumres.2003.08.013.

12. EFSA Panel on Animal Health and Welfare. Scientific Opinion on the use of animal-based measures to assess welfare of dairy cows. EFSA J. 2012, 10, 2554-2635. 